In this issue:

Standards for College Libraries

Inside Washington

Guidelines for Branch Libraries in

Colleges and Universities

Committee Appointed to Write

Quantitative Standards for

"Guidelines for Two-Year College

Learning Resources Programs"

News From the Field

People

Classified Advertising

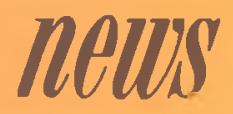

NO. 9 - OCTOBER 1975

\title{
Standards for College Libraries
}

Approved as policy by the Board of Directors of the Association of College and Research Libraries, on July 3, 1975. These Standards supersede and replace the 19.59 "Standards for College Libraries" (College \& Research Libraries, July 1959, p.274-80).

\section{Introduction}

Since the beginning of colleges libraries have been considered an essential part of advanced learning. Their role has ever been to provide access to the human records needed by members of the higher education community for the successful pursuit of academic programs. Total fulfillment of this role, however, is an ideal which has never been and probably never will be attained. Libraries can therefore be judged only by the degree to which they approach this ideal. Expectations moreover of the degree of total success that they should attain are widely various, differing from institution to institution, from individual to individual, from constituency to constituency. It is this diversity of expectations that prompts the need for standards.

The Standards hereinafter presented do not prescribe this unattainable ideal. They rather describe a realistic set of conditions which, if fulfilled, will provide an adequate library program in a college. They attempt to synthesize and articulate the aggregate experience and judgment of the academic library profession as to adequacy in library resources, services, and facilities for a college community. They are intended to apply to libraries serving academic programs at the bachelors and masters degree levels. They may be applied also to libraries serving universities which grant fewer than ten doctoral degrees per year. "They are not designed for use in two-year colleges, larger universities, independent professional schools, specialized programs or other atypical institutions.

These Standards are organized on the basis of the major functions and components of library organization and services and are arranged as follows:

1. Objectives

2. Collections

3. Organization of Materials

4. Staff

5. Delivery of Service

6. Facilities

7. Administration

8. Budget

A brief explanatory exegesis is appended to each Standard, citing the reasons for its inclusion and providing suggestions and comments upon its implementation. Complete background considerations for these commentaries may be found in the literature of librarianship.

There are a number of additional areas wherein standards are felt to be desirable when it is possible to prepare them, but for which no consensus among librarians is apparent at this

- Specifically these Standards address themselves to institutions defined by the Carnegie Commission on Higher Education as Liberal Arts Colleges I and II and Comprehensive Universities and Colleges I and II, in A Classification of Institutions of Higher Education (Berkeley, Cal., 1973). 
time. These include measures of library effectiveness and productivity, the requisite extent and configuration of non-print resources and services, and methods for program evaluation. Research and experimentation should make it possible, however, to prepare standards for them at some future time.

\section{STANDARD I:}

\section{Objectives OF THE LIBRARy}

I The college library shall develop an explicit statement of its objectives in accord with the goals and purposes of the college.

1.1 The development of library objectives shall be the responsibility of the library staff, in consultation with students, members of the teaching faculty, and administrative officers.

1.2 The statement of library objectives shall be reviewed periodically and revised as needed.

\section{Commentary on Standard 1}

The administration and faculty of every college have a responsibility to examine from time to time their education programs and to define the purposes and goals of the institution. Members of the library faculty share in this exercise, and they have thereafter the responsibility to promote library service consistent with institutional aims and methods. Successful fulfillment of this latter responsibility can best be attained when a clear and explicit statement of derivative library objectives is prepared and promulgated so that all members of the college community can understand and evaluate the appropriateness and effectiveness of library activities.

Preparation of library objectives is an obligation of the library faculty with the assistance of the rest of the library staff. In this effort, however, the library should seek in a formal or structured way the advice and guidance of students, of members of the teaching faculty, and of administrative officers. Library objectives should be kept current through periodic review and revision as needed.

In preparing its statement of objectives, the library staff should consider the evolution in recent decades of new roles for the American college library. Although the college library continues as in the past to serve as the repository for the printed information needed by its patrons, its resources have now been extended to embrace new forms of recorded information, and its proper purpose has been enlarged through changes in the scope of the curriculum and by new concepts of instruction. Thus it now serves also as a complementary academic capability which affords to students the opportunity to augment their classroom experience with an independent avenue for learning beyond the course offerings of the institution.
Even this instructional objective of the library, however, must be conceived and formulated within the overall academic purpose of the college.

Standard 2:

\section{The Collections}

2 The library's collections shall comprise all corpuses of recorded information owned by the college for educational, inspirational, and recreational purposes, including multi-dimensional, aural, pictorial, and print materials.

2.1 The library shall provide quickly a high percentage of such materials needed by its patrons.

2.1.1 The amount of print materials to be thus provided shall be determined by a formula (See Formula A) which takes into account the nature and extent of the academic program of the institution, its enrollment, and the size of its teaching faculty.

\section{Commentary on Standard 2}

The records of intellectual endeavor appear in a wide range of formats. Books represent extended reports of scholarly investigation, compilations of findings, creative works, and summaries prepared for educational purposes. The journal has become the common medium for scientific communication and usually represents more recent information. Scientific reports in near-print form are becoming an even faster means of research communication. Documents

News items for inclusion in C\&RL News should be sent to Mary Frances Collins, Assistant Director of Libraries lor Technical Services, University Library ULB-35A, State University of New York at Albany, 1400 Washington Ave., Albany, NY 12222. Advertising (including classified ads) should be sent to Leona Swiech, Advertising Office, American Library Association, 50 E. Huron St. Chicago, IL 60611 . Production and circulation matters are handled by $A L A$ Central Production Unit, at the above address.

Nows ditor: Mary Frances Collins, Assistant Director of Libraries for Technical Services, State University of New York at Albany, Albany. As sociate Nows editor: Anne Dowling Assistant Librarian, Acquisitions Department, Library. Stałe University of New York at Albany. Editor: Richard D. Johnson, Milne Library, State University College, Oreonta, New York I3820. President. ACRL: Louise Giles. Executive Secrelary, ACRL: Beverly P. Lynch.

College Research Libraries is published by the Association of College and Research Libraries, a division of the American Library Association, 17 times yearly-6 bimonthly journal issues and II monthly (combining July-August) News issues-at |201-05 Blulf St. Fulton, MO 6525I. Subscription, $\$ 15.00$ a year, or to members of the division, $\$ 7.50$, included in dues. Second-class postage paid at Fulton, Missouri $6525 \mathrm{~L}$

(C) American Library Association 1975. All material in this journal subject to copyright by the American Library Association may be phofocopied for the noncommercial purpose of seientific or educa. tional advancement. 
represent compilations of information prepared by governmental agencies, and newspapers contain the systematic recording of daily activities throughout the world.

Many kinds of communication can be better and sometimes faster accomplished through such non-print media as films, slides, tapes, radio and television recordings, and realia. Microphotography is an accepted means of compacting many kinds of records for preservation and storage. Recorded information may also come in the form of manuscripts, archives, and machine-readable data bases. Each medium of communication provides unique dimensions for the transmission of information, and each tends to complement the others.

This inherent unity of recorded information, and the fundamental commonality of its social utility, require that regardless of format, all kinds of recorded information needed for academic purposes by an institution be selected, acquired, organized, stored, and delivered for use within the library. In this way the institution's information resources can best be articulated and balanced for the greatest benefit of the entire community.

It is less important that a college hold legal title to the quantity of library materials called for in Formula $A$ than it be able to supply the amount quickly-say within fifteen minutes-as by contract with an adjacent institution or by some other means. An institution which arranges to meet all or part of its library responsibilities in this way, however, must take care that in doing so it not create supernumerary or unreimbursed costs for another institution and that the materials so made available are relevant to its own students' needs.

Since a library book collection once developed, and then allowed to languish, loses its utility very rapidly, continuity of collection development is essential. Experience has shown that even after collections have attained sizes required by this Standard, they can seldom retain their requisite utility without sustaining annual gross growth rates, before withdrawals, of at least five percent.

Higher education has thus far had too little experience with non-print library materials to permit tenable generalizations to be made about their quantitative requirements. Since consensus has not yet been attained among educators as to the range, extent, and configuration of non-print services which it is appropriate for college libraries to offer, no generally applicable formulas are possible here. It is as-

\section{FORMULA A-}

The formula for calculating the number of relevant print volumes (or microform volume-equivalents) to which the library should provide prompt access is as follows (to be calculated cumulatively):

1. Basic Collection

2. Allowance per FTE Faculty Member

3. Allowance per FTE Student

4. Allowance per Undergraduate Major or Minor Field*

5. Allowance per Masters Field, When No Higher Degree is Offered in the Field ${ }^{\circ}$

6. Allowance per Masters Field, When a Higher Degree is Offered in the Field ${ }^{\circ}$

7. Allowance per 6th-year Specialist Degree Field ${ }^{*}$

8. Allowance per Doctoral Field ${ }^{\circ}$

85,000 vols. 100 vols.

15 vols.

350 vols.

6,000 vols.

3,000 vols.

6,000 vols.

25,000 vols.

A "volume" is defined as a physical unit of any printed, typewritten, handwritten, mimeographed, or processed work contained in one binding or portfolio, hardbound or paperbound, which has been cataloged, classified, and/or otherwise prepared for use. For purposes of this calculation microform holdings should be included by converting them to volume-equivalents. The number of volume-equivalents held in microform should be determined either by actual count or by an averaging formula which considers each reel of microform as one, and five pieces of any other microformat as one volume-equivalent.

Libraries which can provide promptly 100 percent as many volumes or volume-equivalents as are called for in this formula shall, in the matter of quantity, be graded A. From 80-99 percent shall be graded B; from $65-79$ percent shall be graded $C$; and from $50-64$ percent shall be graded D.

\footnotetext{
"See Appendix I, "List of Fields."
} 


\section{Standards}

Continued from page 279

sumed, however, that every college library should have non-print resources appropriate to institutional needs.

The goal of college library collection development should be quality rather than quantity. A collection may be said to have quality for its purpose only to the degree that it possesses a portion of the bibliography of each discipline taught, apropriate in quantity both to the level at which each is taught and to the number of students and faculty members who use it. Quality and quantity are separable only in theory: it is possible to have quantity without quality; it is not possible to have quality without quantity defined in relation to the purposes of the institution. No easily applicable criteria have been developed, however, for measuring quality in library collections.

The best way to assure quality in a college library collection is to gain it at point of input. Thus rigorous discrimination in the selection of materials to be added to the library's holdings, whether as purchases or gifts, is of considerable importance. Care should be exerted to select a substantial portion of the titles listed in the standard, scholarly bibliographies reflecting the curriculum areas of the college and supporting general fields of knowledge. A number of such subjects lists for college libraries have been prepared by learned associations. Among general bibliographies Books for College Libraries is useful especially for purposes of identifying important retrospective titles. For current additions, provision should be made to acquire a majority of the significant new publications reviewed in Choice. Generous attention should be given also to standard works of reference and to bibliographical tools which provide access to the broad range of scholarly sources as listed in Winchell's Guide to Reference Books. Institutional needs vary so widely for periodical holdings that quantitative standards cannot be written for them at this time, but in general it is good practice for a library to own any title that is needed more than six times per year. Several good handlists have been prepared of periodical titles appropriate for college collections.

College library collections should be evaluated continuously against standard bibliographies and against records of their use, for purposes both of adding to the collections and identifying titles for prompt withdrawal once they have outlived their usefulness to the college program. No book should be retained in a college library for which a clear purpose is not evident in terms of the institution's current or anticipated academic program; when such clear purpose is lacking, a book should be retired from the collections.
Although in the last analysis the library staff must be responsible for the scope and content of the collections, it can best fulfill this responsibility with substantial help and consultation from the teaching faculty and from students. Of greatest benefit to the library is continuing faculty assistance in defining the literature requirements of the courses in the curriculum, definitions which should take the form of written selection policies. In addition, members of the teaching faculty may participate in the selection of individual titles to be obtained. If this latter activity, however, is carried out largely by the library, then the teaching faculty should review the books acquired both for their appropriateness and the quality of their contents.

\section{StANDARD 3: \\ Organization of Materials}

3 Library collections shall be organized by nationally approved conventions and arranged for efficient retrieval at time of need.

3.1 There shall be a union catalog of the library's holdings that permits identification of items, regardless of format, by author, title, and subject.

3.1.1 The catalog may be developed either by a single library or jointly among several libraries.

3.1.2 The catalog shall be in a format that can be consulted by a number of people concurrently and at time of need.

3.1.3 In addition to the catalog there shall also be requisite subordinate files, such as serial records, shelf lists, authority files, and indexes to nonmonographic materials.

3.2 Except for certain categories of material which are for convenience best segregated by form, library materials shail be arranged on the shelves by subject.

3.2.1 Patrons shall have direct access to library materials on the shelves.

\section{Commentary on Standard 3}

The acquisition alone of library materials comprises only part of the task of providing access to them. Collections must be indexed and systematically arranged on the shelves before their efficient identification and retrieval at time of need, which is an important test of a good library, can be assured. For most library materials this indexing can best be accomplished through the development of a union catalog with items entered in accord with established national or international bibliographical conventions, such as rules for entry, descriptive cataloging, filing, classification, and subject headings.

Opportunities of several kinds exist for the cooperative development of the library's cata$\log$, through which economy can be gained in 
its preparation. These include the use of centralized cataloging by the Library of Congress and the joint compilation of catalogs by a number of libraries. Joint catalogs can take the form of card files, book catalogs, or computer files. Catalogs jointly developed, regardless of format, can satisfy this Standard provided that they can be consulted-under author, title, or subject-by a number of library patrons concurrently at their time of need. Catalogs should be subject to continual editing to keep them abreast of modern terminology, current technology, and contemporary practice.

Proper organization of the collections will also require the maintenance of a number of subordinate files, such as authority files and shelf lists, and of complementary catalogs, such as serial records. Information contained in these files should also be available to library users. In addition, some library materials such as journals, documents, and microforms are often indexed centrally by commercial or quasi-commercial agencies, and in such cases access should be provided to those indexes as needed, whether they be in published or computerbased format.

Materials should be arranged on the shelves by subject matter so that related information can be consulted together. Some kinds of materials, however, such as maps, microforms, and non-print holdings, may be awkward to integrate physically because of form and may be segregated from the main collection. Other materials, such as rarities and manuscripts or archives, may be segregated for purposes of security. Materials in exceptionally active use, such as bibliographies, works of reference, and assigned readings, may be kept separate to facilitate access to them. Except in such cases, however, the bulk of the collections should be classified and shelved by subject in open stack areas so as to permit and encourage browsing.

\section{STANDARD 4: STAFF}

The library staff shall be of adequate size and quality to meet agreed-upon objectives.

4.1 The staff shall comprise qualified librarians, skilled supportive personnel, and part-time assistants serving on an hourly basis.

4.2 The marks of a librarian shall include a graduate library degree from an ALA-accredited program, responsibility for duties of a professional nature, and participation in professional library affairs beyond the local campus.

4.2.1 The librarians of a college shall be organized as an academic department-or, in the case of a university, as a schooland shall administer themselves in accord with ACRL "Standards for Faculty Status for College and University Librarians" (See Appendix II).

4.3 The number of librarians required shall be determined by a formula (Formula $\mathrm{B}$, below) which takes into account the enrollment of the college and the size and growth rate of the collections.

4.3.1 There shall be an appropriate balance of effort among librarians, supportive personnel, and part-time assistants, so that every staff member is employed as nearly as possible commensurate with his library training, experience, and capability.

4.4 Library policies and procedures concerning staff shall be in accord with sound personnel management practice.

\section{Commentary on Standard 4}

The college library will need a staff comprising librarians, supportive personnel, and parttime assistants to carry out its stated objectives. The librarian has acquired through training in a graduate library school an understanding of the principles and theories of selection, acquisition, organization, interpretation, and administration of library resources. Supportive staff members have normally received specialized or on-the-job training for particular assignments within the library; such assignments can range

\section{FORMULA B-}

The number of librarians required by the college shall be computed as follows (to be calculated cumulatively):

For each 500 , or fraction thereof, FTE students up to 10,000

For each 1,000 or fraction thereof, FTE students above 10,000

1 librarian

For each 100,000 volumes, or fraction thereof, in the collection

1 librarian

For each 5,000 volumes, or fraction thereof, added per year

1 librarian

1 librarian

Libraries which provide 100 percent of these formula requirements can, when they are supported by sufficient other staff members, consider themselves at the A level in terms of staff size; those that provide 75-99 percent of these requirements may rate themselves as B; those with 55-74 percent of requirements qualify for a $C$; and those with $40-54$ percent of requirements warrant a $\mathrm{D}$. 
in complexity from relatively routine or business functions to highly technical activities often requiring university degrees in fields other than librarianship. Well managed college libraries also utilize some part-time assistants, many of whom are students. Although they must often perform repetitive and more perfunctory work, given good training and adequate experience such assistants can often perform at relatively skilled levels and constitute an important segment of the library team.

Work assignments, both to these several levels and to individuals, should be carefully conceived and allocated so that all members of the library staff are employed as nearly as possible commensurate with their library training, experience, and capability. This will mean that the librarians will seldom comprise more than 25-35 percent of the total FTE library staff.

The librarians of a college comprise the faculty of the library and should organize and administer themselves as any other departmental faculty in the college (or in the case of the university, the library faculty is equivalent to a school faculty, and should govern itself accordingly). In either case, however, the status, responsibilities, perquisites, and governance of the library faculty shall be fully recognized and supported by the parent institution, and it shall function in accord with the ACRL "Standards for Faculty Status for College and University Librarians."

The staff represents one of the library's most important assets in support of the instructional program of the college. Careful attention is therefore required to proper personnel management policies and procedures. Whether administered centrally for the college as a whole or separately within the library, these policies and practices must be based upon sound, contemporary management understanding consistent with the goals and purposes of the institution. This will mean that:

1. Recruitment methods should be based upon a careful definition of positions to be filled, utilization of a wide range of sources, qualifications based upon job requirements, and objective evaluation of credentials.

2. Written procedures should be followed in matters of appointment, promotion, tenure, dismissal, and appeal.

3. Every staff member should be informed in writing as to the scope of his responsibilities and the individual to whom he is responsible.

4. Classification and pay plans should give recognition to the nature of the duties performed, training and experience required, and rates of pay and benefits of other positions requiring equivalent background.

5. There should be provided a structured program for the orientation and training of new staff members and opportunities for the continuing education of existing staff.
6. Supervisory staff should be selected on the basis of job knowledge and human relations skills and provide training in these responsibilities as needed.

7. Systems should be maintained for periodic review of employee performance and for recognition of achievement.

8. Career opportunities and counseling should be made available to library staff members at all levels and in all departments.

STANDARD 5:

Delivery of Service

5 The college library shall establish and maintain a range and quality of services that will promote the academic program of the institution and encourage optimal library use.

5.I Proper service shall include: the provision of continuing instruction to patrons in the effective exploitation of libraries; the guidance of patrons to the library materials they need; and the provision of information to patrons as appropriate.

5.2 Library materials shall be circulated to qualified patrons under equitable policies and for as long periods as possible without jeopardizing their availability to others.

5.2.1 The availability of reading materials shall be extended wherever possible by the provision of inexpensive means of photocopying.

5.2.2 The quality of the collections available locally to patrons shall be enhanced through the use of "National Interlibrary Loan Code 1968" (See Appendix II) and other cooperative agreements which provide reciprocal access to multi-library resources.

5.3 The hours of public access to the materials on the shelves, to the study facilities of the library, and to the library staff, shall be consistent with reasonable demand, both during the normal study week and during weekends and vacation periods.

5.4 Where academic programs are offered away from a campus, library services shall be provided in accord with ACRL's "Guidelines for Library Services to Extension Students" (See Appendix II).

\section{Commentary on Standard 5}

The primary purpose of college library service is to promote the academic program of the parent institution. The successful fulfillment of this purpose will require that librarians work closely with teaching faculty to gain an intimate knowledge of their educational objectives and methods and to impart to them an understanding of the services which the library can 
render. Both skill in library use and ease of access to materials can encourage library use, but the major stimulus for students to use the library has always been, and likely always will be, the instructional methods used in the classroom. Thus close cooperation between librarians and classroom instructors is essential.

Such cooperation does not come about fortuitously; it must be a planned and structured activity, and it must be assiduously sought. It will require not only that librarians participate in the academic planning councils of the institution but also that they assist teaching faculty in appraising the actual and potential library resources available, work closely with them in developing library services for new courses and new pedagogical techniques, and keep them informed of new library capabilities.

A key service of a college library is the introduction and interpretation of library materials to patrons. This activity takes several forms. The first form is instruction in bibliography and in the use of information tools. It will also familiarize patrons with the physical facilities of the library, its services and collections, and the policies and conditions which govern their use. Bibliographic instruction and orientation may be given at many levels of sophistication and may use a variety of instructional methods and materials, including course-related instruction, separate courses with or without credit, group or individualized instruction, utilizing print or non-print materials.

The second basic form which interpretation will take is conventional reference work wherein individual patrons are guided by librarians in their appraisal of the range and extent of the library resources available to them for learning and research, in the most effective marshalling of that material, and in the optimal utilization of libraries. Most library interpretative work is of this kind.

The third major genre of library interpretation is the delivery of information itself. Although obviously inappropriate in the case of student searches which are purposeful segments of classroom assignments, the actual delivery of information-as distinct from guidance to it-is a reasonable library service in almost all other conceivable situations.

As regards the circulation of library materials, the general trend in recent years has been toward longer loan periods, but these periods must be determined by local conditions which will include size of the collections, the number of copies of a book held, and the extent of the user community. Circulation should be for as long periods as are reasonable without jeopardizing access to materials by other qualified patrons. This overall goal may prompt some institutions to establish variant or unique loan periods for different titles or classes of titles. Whatever loan policy is used, however, it should be equitably and uniformly administered to all qualified categories of patrons.

Locally-held library resources should be extended and enhanced in every way possible for the benefit of library patrons. Both the quantity and the accessibility of reading materials can be extended through the provision of inexpensive means of photocopying within the laws regarding copyright. Local resources should aso be extended through the provision and encouragement of reciprocal arrangements with other libraries as through the "National Interlibrary Loan Code 1968" and joint-access consortia. Beyond its own local constituency every library also has a responsibility to make its holdings available to other students and scholars in at least three ways-in-house consultation, photocopy, and through interlibrary loan.

The number of hours per week that library services should be available will vary, depending upon such factors as whether the college is in an urban or rural setting, teaching methods used, conditions in the dormitories, and whether the student body is primarily resident or commuting. In any case, library scheduling should be responsive to reasonable local need, not only during terma-time week-days but also on weekends, and, especially where graduate work is offered, during vacation periods. In many institutions readers may need access to study facilities and to the collections during more hours of the week than they require the personal services of librarians. The public's need for access to librarians may range upward to one hundred hours per week, whereas around-the-clock access to the library's collections and/or facilities may in some cases be warranted.

Special library problems exist for colleges that provide off-campus instructional programs. Students in such programs must be provided with library services in accord with ACRL's "Guidelines for Library Services to Extension Students." These Guidelines require that such services be financed on a regular basis, that a librarian be specifically charged with the delivery of such services, that the library implications of such programs be considered before program approval, and that courses so taught encourage library use. Such services, which are especially important at the graduate level, must be furnished despite their obvious logistical problems.

\section{Standard 6: \\ FACILITIES}

6 The college shall provide a library building containing secure facilities for housing its resources, adequate space for administration of those resources by staff, and comfortable quarters and furnishings for their utilization by patrons.

6.1 The size of the library building shall be de- 
termined by a formula (See Formula C) which takes into account the enrollment of the college, the extent and nature of its collections, and the size of its staff.

6.2 The shape of the library building and the internal distribution of its facilities and services shall be determined by function.

6.3 Except in unusual circumstances, the college library's collections and services shall be administered within a single structure.

\section{Commentary on Standard 6}

Successful library service presupposes an adequate library building. Although the type of building provided will depend upon the character and the aims of the institution, it should in all cases present secure facilities for housing the library's resources, sufficient space for their administration by staff, and comfortable quarters and furnishings for their utilization by the public, all integrated into a functional and esthetic whole. The college library building should represent a conscious planning effort, involving the librarian, the college administration, and the architect, with the librari- an responsible for the preparation of the building program. The needs of handicapped patrons should receive special attention in the designing of the library building.

Many factors will enter into a determination of the quality of a library building. They will include such esthetic considerations as its location on the campus, the grace with which it relates to its site and to neighboring structures, and the degree to which it contributes esthetically to the desired ambience of the campus. They will also include such internal characteristics as the diversity and appropriateness of its accommodations and furnishings, the functional distribution and interrelationships of its spaces, and the simplicity and economy with which it can be utilized by patrons and operated by staff. They will include moreover such physical characteristics as the adequacy of its acoustical treatment and lighting, the effectiveness of its heating and cooling plant, and the selection of its movable equipment.

Decentralized library facilities in a college have some virtues, and they present some difficulties. Primary among their virtues is their

\section{FORMULA C-}

The size of the college library building shall be calculated on the basis of a formula which takes into consideration the size of the student body, requisite administrative space, and the number of physical volumes held in the collections. In the absence of consensus among librarians and other educators as to the range of non-book services which it is appropriate for libraries to offer, no generally applicable formulas have been developed for calculating space for them. Thus, space required for a college library's non-book services and materials must be added to the following calculations:

a. Space for readers. The seating requirement for the library of a college wherein less than fifty percent of the FTE enrollment resides on campus shall be one for each five FTE students; the seating requirement for the typical residential college library shall be one for each four FTE students; and the seating requirements for the library in the strong, liberal arts, honors-oriented college shall be one for each three FTE students. In any case, each library seat shall be assumed to require twenty-five square feet of floor space.

b. Space for books. Space required for books depends in part upon the overall size of the book collection, and is calculated cumulatively as follows:

For the first 150,000 volumes

For the next 150,000 volumes

For the next 300,000 volumes $\quad 0.08$

Square Feet/Volume 0.10

0.09

For holdings above 600.000 volumes $\quad 0.07$

c. Space for administration. Space required for such library administrative activities as acquisition, cataloging, staff offices, catalogs, and files shall be one-fourth of the sum of the spaces needed for readers and books as calculated under (a) and (b) above.

This tripartite formula indicates the net assignable area necessary for all library services except for non-book services. (For definition of "net assignable area" see "The Measurement and Comparison of Physical Facilities for Libraries," produced by ALA's Library Administration Division. See Appendix II.) Libraries which provide 100 percent as much net assignable area as is called for by the formula shall qualify for an A rating as regards quantity; 75-99 percent shall warrant a $\mathrm{B}$; 60-74 percent shall be due a $\mathrm{C}$; and 50-59 percent shall warrant a $D$. 
adjacency to the laboratories and offices of some teaching faculty members within their service purview. Primary among their weaknesses are their fragmentation of unity of knowledge, their relative isolation from library users (other than aforementioned faculty), the fact that they can seldom command the attention of qualified staff over either long hours during a week or over a sustained period of time, and the excessive costs of creating duplicate catalogs, periodical lists, circulation services, and attendant study facilities. Where decentralized library facilities are being considered, these costs and benefits must be carefully compared. In general, experience has shown that except where long distances are involved, decentralized library facilities are at the present time unlikely to be in the best pedagogical or economic interests of a college.

\section{STANDARD 7: \\ ADMINISTRATION}

$7 \quad$ The college library shall be administered in a manner which permits and encourages the fullest and most effective use of available library resources.

7.1 The statutory or legal foundation for the library's activities shall be recognized in writing.

7.2 The college librarian shall be a member of the library faculty and shall report to the president or the chief academic officer of the institution.

7.2.1 The responsibilities and authority of the college librarian and procedures for his appointment shall be defined in writing.

7.3 There shall be a standing advisory committee comprising students and members of the teaching faculty which shall serve as the main channel of formal communication between the library and its user community.

7.4 The library shall maintain written policies and procedure manuals covering internal library governance and operational activities.

7.4.1 The library shall maintain a systematic and continuous program for evaluating its performance and for identifying needed improvements.

7.4.2 The library shall develop statistics not only for purposes of planning and control but also to aid in the preparation of reports designed to inform its publics of its accomplishments and problems.

7.5 The library shall develop, seek out, and utilize cooperative programs for purposes of either reducing its operating costs or enhancing its services, so long as such programs create no unreimbursed or unreciprocated costs for other libraries or organizations.
7.6 The library shall be administered in accord with the spirit of the ALA "Library Bill of Rights." (See Appendix II.)

\section{Commentary on Standard 7}

Much of the commentary on general administration of the college library is gathered under the several other Standards. Matters of personnel administration, for example, are discussed under Standard 4, and fiscal administration is glossed under Standard 8. Some important aspects of library management, however, must be considered apart from the other Standards.

Primary among administrative considerations which are not part of other Standards is the matter of the responsibilities and authority both of the library as an organization and of the college librarian as a college officer. No clear set of library objectives, no tenable program of collection development, no defensible library personnel policy can be developed unless there is first an articulated and widespread understanding within the college as to the statutory, legal or other basis under which the library is to function. This may be a college bylaw, or a trustee minute, or a public law which shows the responsibility and flow of authority under which the library is empowered to act. There must also be a derivative document defining the responsibility and authority vested in the office of the college librarian. This document may also be statutorily based and should spell out, in addition to the scope and nature of his duties and powers, the procedures for his appointment and the focus of his reporting responsibility. Experience has shown that, for the closest coordination of library activities with the instructional program, the college librarian should report either to the president or to the chief officer in charge of the academic affairs of the institution.

Although the successful college library must strive for excellence in all of its communications, especially those of an informal nature, it must also have the benefit of an advisory committee representing its user community. This committee-of which the college librarian should be an ex officio member-should serve as the main channel of formal communication between the library and its publics and should be used to convey both an awareness to the library of its patrons' concerns, perceptions, and needs, and an understanding to patrons of the library's capabilities and problems. The charge to the committee should be specific, and it should be in writing.

Many of the precepts of college library administration are the same as those for the administration of any other similar enterprise. The writing down of policies and the preparation of procedures manuals, for example, are re- 


\section{Combined Indexes}

Library of Congr Classification Sche

Compiled By Nancy B. Olson, Mankato St

For Years ... library authorities have recognized and encouraged the growing of Congress Classification system in various types and sizes of libraries.

Also for Years .... they have expressed the need for combined indexes linki classification schedules-indexes which would bring together all the terms that relate PERSON, PLACE or SUBJECT in the system. HERE THEY ARE!

\section{PERSONS}

8. Set I. AUTHOR/NUMBER INDEX TO THE LIBRARY OF CONGRESS CLASSIFICATION SCHEDULES, 1974. 2 Volumes, Cloth Bound, postpaid in North America $\$ 162.00$ 9 का की SEt II. BIOGRAPHICAL SUBJECT TO THE LIBRARY OF CONGRESS CLASSIFICATION SCHEDULES, 1974. 3 Volumes, Cloth Bound. postpaid in North America $\$ 228.00$ ब. Set III. CLASSIFIED INDEX TO PERSONS IN THE LIBRARY OF CONGRESS CLASSIFICATION SCHEDULES, 1974. 3 Volumes, Cloth Bound, postpaid in North America $\$ 228.00$

\section{PLACES}

(9)

Set IV. GEOGRAPHIC LIBRARY OF CONGRESS CLAS 1974. 1 Volume, Cloth Bound,

\section{SUBJECTS}

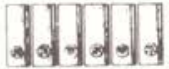

Set V. SUBJE THE LIBRARY OF CONGRESS ULES, 1974. 6 Volumes, Cloth America

THE COMPLETE SET OF COMBINED INDEXES CONTAINS MORE THAN

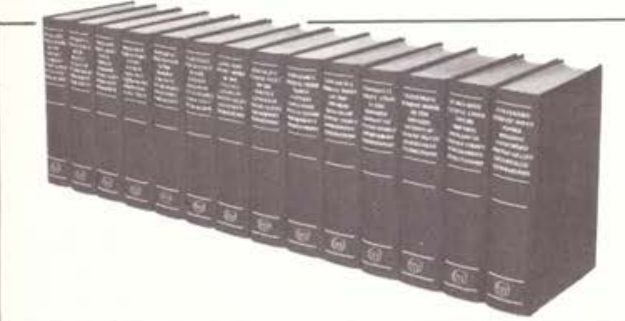

The complete 15 volume set of COMBINED LIBRARY OF CONGRESS CLASSIFICATIC FIRST EDITION, 1974. Cloth Bound, pc America 


\section{o the}

SS

dules

e University

Ise of the Library

\section{all 31 separate}

every

NAME INDEX TO THE ICATION SCHEDULES, tpaid in North America

$\$ 80.00$

KEYWORD INDEX TO ASSIFICATION SCHED-

und, postpaid in North

$\$ 463.00$

\section{, 000 ENTRIES}

DEXES TO THE SCHEDULES, paid in North $\$ 1,145.00$
Now for the first time catalogers, reference librarians and researchers need look in only one place for LC class numbers and still be confident that they covered all aspects of every subject cited in the schedules.

\section{In Reference Work}

The acquisition of these new Combined Indexes will enhance the accessibility - and hence the overall reference value-of all types of library collections in which the LC Classification system is being used or contemplated.

The single-alphabet arrangement of the personal name indexes brings together in one place all numbers assigned to persons prominent in several fields, as well as to authors who have written in more than one language. Entries show class numbers with the proper form of each name as well as cross references and pseudonyms.

In the case of geographical names, the bringing together of class numbers for all the various terms in the system which might apply to any given country or area, marks a major reference achievement in itself.

Meanwhile, the specificity of the hundreds of thousands of keywords sorted alphabetically in the general Subject Keyword index offers researchers a means of identifying subject-oriented classes with in-depth accuracy not previously possible.

The "classified" indexes to authors and other persons will also prove to be major reference tools, as they will bring together the numbers of individuals in various categories and time-periods for use in various types of comparative studies.

\section{In Cataloging}

The personal name indexes will be invaluable as the first sources to consult when cataloging a literary work or biography. In the larger libraries they will replace many lengthy searches in the National Union Catalog. In smaller libraries without access to the NUC, the combined indexes will enable catalogers to find and use correct classifications immediately, rather than having to contact other llbraries or resort to creating their own class numbers.

The massive single-alphabet Keyword Subject Index will also prove to be a major cataloging tool for both large and small ibraries. In the larger systems where catalogers are specialists and hence familiar with their assigned portions of the schedules, the major advantages of the combined index set lie in its convenient one-step format and the added dimension of its in-depth keyboard subject indexing. For new catalogers or lone catelogers in small libraries, for whom identifying correct schedules is a time-consuming problem in itself, the combined indexes offer an immediate additional advantage.

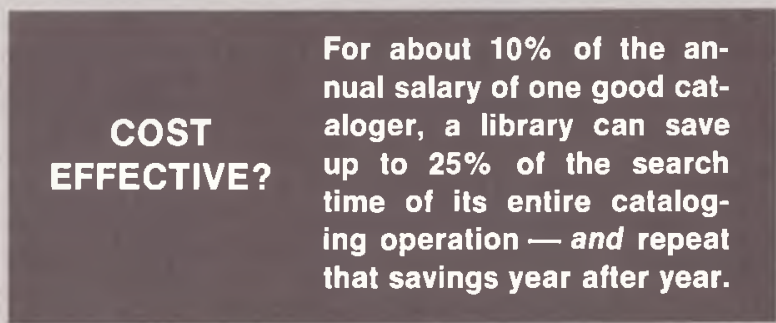


quired for best management of any organization so as to assure uniformity and consistency of action, to aid in training of staff, and to contribute to public understanding. Likewise sound public relations are essential to almost any successful service organization. Although often observed in their omission, structured programs of performance evaluation and quality control are equally necessary. All of these administrative practices are important in a well managed library.

Some interlibrary cooperative efforts have tended in local libraries to enhance the quality of service or reduce operating costs. Labor-sharing, for example, through cooperative processing programs has been beneficial to many libraries, and participation in the pooled ownership of seldom-used materials has relieved pressure on some campuses for such materials to be collected locally. The potential values of meaningful cooperation among libraries are sufficient to require that libraries actively search out and avail themselves of cooperative programs that will work in their interests. Care should be taken, however, to assure that a recipient library reimburse, either in money or in kind, the full costs of any other institution that supplies its service, unless of course the supplying institution is specifically charged and funded so to make its services available.

College libraries should be impervious to the pressures or efforts of any special interest groups or individuals to shape their collections and services in accord with special pleadings. This principle, first postulated by the American Library Association in 1939 as the "Library Bill of Rights," should govern the administration of every college library and be given the full protection of all parent institutions.

\section{Standard 8: BUDGET}

8 The college librarian shall have the responsibility for preparing, defending, and administering the library budget in accord with agreed-upon objectives.

8.1 The amount of the library appropriation shall express a relationship to the total institutional budget for educational and general purposes.

8.2 The librarian shall have sole authority to apportion funds and initiate expenditures within the library approved budget, in accord with institutional policy.

8.3 The library shall maintain such internal accounts as are necessary for approving its invoices for payment, monitoring its encumberances, and evaluating the flow of its expenditures.

\section{Commentary on Standard 8}

The library budget is a function of program planning and tends to define the library's objec- tives in fiscal terms and for a stated interval of time. Once agreed to by the college administration, the objectives formulated under Standard 1 should constitute the base upon which the library's budget is developed. The degree to which the college is able to fund the library in accord with its objectives is reflected in the relationship of the library appropriation to the total educational and general budget of the college. Experience has shown that library budgets, exclusive of capital costs and the costs of physical maintenance, which fall below six percent of the college's total educational and general expenditures are seldom able to sustain the range of library programs required by the institution. This percentage moreover will run considerably higher during periods when the library is attempting to overcome past deficiencies, to raise its "grade" on collections and staff as defined elsewhere in these Standards, or to meet the information needs of new academic programs.

The adoption of formulas for preparation of budget estimates and for prediction of library expenditures over periods of time are relatively common, especially among public institutions. Since such formulas can often provide a gross approximation of needs, they are useful for purposes of long-range planning, but they frequently fail to take into account local cost variables, and they are seldom able to respond promptly to unanticipated market inflation or changes in enrollment. Thus they should not be used, except as indicators, in definitive budget development.

Among the variables which should be considered in estimating a library's budget requirements are the following:

1. The scope, nature, and level of the college curriculum;

2. Instructional methods used, especially as they relate to independent study;

3. The adequacy of existing collections and the publishing rate in fields pertinent to the curriculum;

4. The size, or anticipated size, of the student body and teaching faculty;

5. The adequacy and availability of other library resources in the locality to which the library has contracted access;

6. The range of services offered by the library, the number of service points maintained, the number of hours per week that service is provided, etc.;

7. The extent to which the library already meets the Standards defined in these pages.

Procedures for the preparation and defense of budget estimates, policies on budget approval, and regulations concerning accounting and expenditures may vary from one institution or jurisdiction to another, and the college librarian must know and conform to local practice. In any circumstance, however, sound prac- 
tices of planning and control require that the librarian have sole responsibility and authority for the allocation-and within college policy, the reallocation-of the library budget and the initiation of expenditures against it. Depending upon local factors, between 35 and 45 percent of the library's budget is normally allocated to the purchase of materials, and between 50 and 60 percent is expended for personnel.

The preparation of budget estimates may be made on the basis of past expenditures and anticipated needs, comparison with similar libraries, or statistical norms and standards. More sophisticated techniques for detailed analysis of costs by library productivity, function, or program-as distinct from items of expenditure -have been attempted in some libraries. Such procedures require that the library develop quantitative methods by which to prepare estimates, analyze performance, and determine the relative priority of services rendered. Although this kind of budgeting, once refined, may lead to more effective fiscal control and greater accountability, libraries generally have thus far had too limited experience with program budgeting or input-output analysis to permit their widespread adoption at this time.

\section{APPENDIX I}

List of Fields

(Count each line as one program)

\section{Advertising}

Afro-American/Black Studies

Agriculture \& Natural Resources

Agricultural Biology

Agricultural Business

Agricultural Chemistry

Agricultural Economics

Agricultural Education

Agricultural Engineering: See Engineering

Agriculture

Agronomy

Animal Science

Crop Science: See Agronomy

Dairy Science

Fisheries

Food Industries

Forestry

Fruit Science and Industry

International Agriculture

Mechanized Agriculture

National Resources Management

Ornamental Horticulture

Poultry Industry

Range Management

Soil Science

Veterinary, Pre-

Watershed Management

Wildlife Management

American Studies

Anthropology

Architecture (See also City Plg.; Engr.; Landscape Arch)
Art

Art History

Asian Studies (See also East Asian)

Astronomy

Behavioral Sciences

Bilingual Studies

Biochemistry

Biology, Biological Sciences (See also Botany, Microbiology, etc.)

Biology and Mathematics

Black Studies: See Afro-American

Botany

Business Administration

Accounting

Business Administration

Business Economics

Business Education

Business, Special interest

Business Statistics

Data Processing

Finance

Hotel and Restaurant Management

Industrial Relations

Information Systems: Listed alphabetically under "I"

Insurance

International (World) Business

Management (Business)

Marketing (Management)

Office Administration

Operations Research (Management Science)

Personnel Management

Production/Operations Management

Public Relations

Quantitative Methods

Real Estate

Secretarial Studies

Transportation Management

Cell Biology

Chemical Physics

Chemistry

Chinese

City/Regional/Urban Planning

Classics

Communications

Communicative Disorders See Speech Pathology

Comparative Literature

Computer Science

Corrections: See Criminal Justice

Creative Writing

Crime, Law and Society

Criminalistics (Forensic Science)

Criminal Justice Administration

Criminal Justice-Corrections

Criminal Justice-Security

Criminology

Cybernetic Systems

Dance

Dietetics and Food Administration

Drama (Theater Arts)

Earth Sciences

East Asian Studies

Ecology/Environmental Biology (See also Environmental Studies)

Economics 
Education

Adult Secondary

Child Development

Counseling/Guidance

Curriculum and Instruction

Culturally Disadvantaged

Deaf

Education

Educational Administration

Educational Foundations and Theory

Educational Psychology

Educational Research

Educational Supervision

Elementary Education

Gifted

Health and Safety

Instructional Media

(Audio-Visual)

Learning Disabilities

(Handicapped)

Mentally Retarded

Orthopedically Handicapped

Reading Instruction

School Psychology: See Psychology

Secondary Education

Special Education

Special Education Supervision

Special Interest

Visually Handicapped

Visually Handicapped:

Orientation and Mobility

Engineering

Aeronautical Engineering, Aerospace and Maintenance

Aeronautics (Operations)

Agricultural

Air Conditioning, Air Pollution:

See Environmental Engineering

Architectural

Biomedical Engineering

Chemical

Civil

Computer

Construction

Electrical

Electrical/Electronic

Electronic

Engineering

Engineering Materials

Engineering Mechanics

Engineering Science

Engineering Technology

Environmental

Environmental Resources

Industrial Administration

Industrial Engineering

Measurement Science

Mechanical

Metallurgical

Nuclear

Ocean

Structural

Surveying and Photogrammetry

Systems

Transportation

Water Pollution: See Environmental

Water Resources
English

English as a Second Language

Entomology

Environmental Studies

Ethnic Studies (See also Afro-American and Mexican-American)

European Studies

Expressive Arts: See Fine and Creative Arts

Film

Fine and Creative Arts

Foods and Nutrition: See Dietetics

French

Genetics

Geography

Geology

German

Government: See Political Science

Government-Journalism

Graphic Communications (Printing)

Graphic Design

Health and Safety: See Education

Health, Public (Environmental)

Health Science

History

Home Economics

Hotel Management: See Business

Humanities

Human Development

Human Services

Hutchins School

India Studies

Industrial Arts

Industrial Design

Industrial Technology

Information Systems

Interior Design

International Relations

Italian

Japanese

Journalism ( see also Communications)

Landscape Architecture

Language Arts

Latin American Studies

Law Enforcement: See Criminal Justice

Liberal Studies

Library Science

Linguistics

Literature (See also English)

Marine Biology

Marriage and Family Counseling

Mass Communications: See Communications

Mathematics

Mathematics, Applied

Medical Biology: See Medical Laboratory Technology

Medical Laboratory Technology (Clinical Science)

Meteorology

Mexican-American/La Raza Studies

Microbiology

Music Education

Music (Liberal Arts)

Music (Performing)

Natural Resources: See Agriculture

Natural Science

Nursing ( See also Health Sciences)

Occupational Therapy 
Oceanography

Park Administration

Philosophy

Philosophy and Religion

Physical Education

(Men)

(Women)

Physical Science

Physical Therapy

Physics

Physiology

Police Science: See Criminal Justice

Political Science

Psychology

Clinical

College Teaching

Developmental

Educational: See Education

Industrial

Physiological

Psychology

Research

School

Social

Public Administration

Public Relations: See Business category or Communications degrees

Radiological and Health Physics

Radio-Television (Telecommunications )

Recreation Administration

Rehabilitation Counseling

Religious Studies

Russian

Russian Area Studies

Social Sciences (See also Anthropology, Sociology, etc.)

Social Welfare and Services

Sociology

Spanish

Special Major

Speech and Drama

Speech Communication

Speech Pathology and Audiology

Communicative Disorders

Statistics

Theater Arts: See Drama

Urban Planning: See City Planning

Urban Studies

Vocational Education

Zoology

\section{APPENDIX II}

Other Works Cited

"[ACRL] Standards for Faculty Status for College and University Librarians." College and Research Libraries News (September 1972), 33:210-12.

"[ACRL] Guidelines for Library Services to Extension Students." ALA Bulletin (January 1967), 61:50-55.

"The Measurement and Comparison of Physical Facilities for Libraries"; typescript. Chicago: American Library Association, Library Administration Division, 1969. 17pp.

"Library Bill of Rights." ALA Handbook of Organization 1974-1975. p.93.
“National Interlibrary Loan Code, 1968." Chicago: American Library Association, Reference and Adult Services Division. 4pp.

The "Standards for College Libraries" were first prepared by a committee of ACRL and promulgated in 1959. The present 1975 revision was prepared by the ACRL Ad Hoc Committee to Revise the 1959 Standards. Members were Johnnie Givens, Austin Peay State University (Chairman): David Kaser, Graduate Library School, Indiana University (Project Director and Editor); Arthur Monke, Bowdoin College; David L. Perkins, California State University, Northridge; James W. Pirie, Lewis \& Clark College; Jasper G. Schad, Wichita State University; and Herman L. Totten, School of Librarianship, University of Oregon.

The effort was supported by a J. Morris Jones-World Book Encyclopedia-ALA Goals Award.

Copies of these Standards are available, upon request, from the ACRL Office, $50 \mathrm{E}$. Huron St., Chicago, IL 60611.

ACRL Membership

August 31, 1975

August 31, 1974

13,497

August 31, 1973

\section{Because publishers are not imprints to us-you benefit}

Our close, personal contact with publishers in the U.S. and all over the world gives you many advantages. Our library experts on-the-spot in New York, London, Paris and Stuttgart.... our world-wide network of agents talk the local publishers' language. They know the markets intimately and avoid problems by anticipating them. Stechert Macmillan's person-to-person contact means better service for your library. Contact us today. Ask for our International Acquisition Services brochure or a representa. tive. You'll be surprised at how helpful we can be.

\section{Let's talk!}

\section{STECHERT MACMILAN, INC. \\ INTERNATIONAL ACQUISITION SERVICES Serving Libraries Since 1872}

866 Third Avenue • New York, N.Y. 10022

(212) 935-4251

NEW YORK • LONDON • PARIS • STUTTGART 


\title{
A DICTIONARY OF COLONIAL AMERICAN PRINTERS' ORNAMENTS AND ILLUSTRATIONS
}

By Elizabeth Carroll Reilly, 520 pp. (approx.), illus. (American Antiquarian Society)

This magnificent book reproduces in striking detail more than 2,000 printers' ornaments and illustrations that appeared in books, pamphlets, and broadsides printed in the American colonies. Students of American printing will now have data to identify otherwise unplaced printed specimens. Others interested in early American culture will have before them as extensive a record as possible of one very special, but ubiquitous, art form.

\section{THE RED BADGE OF COURAGE}

Volume II of the Works of Stephen Crane

Edited by FREDSON Bowers

Introduction by J. C. LeVENSON. xlii, $404 p p$. (Center for Editions of American Authors)

The text of The Red Badge of Courage is established for the first time by use of the Barrett-Virginia manuscript that served as printer's copy for the first edition. The apparatus here enables a critic to reconstruct the five levels of changes made in the final manuscript during its composition and revision (as well as those of the draft), the unauthoritative editing and cutting of the newspaper version, and all differences between the manuscript and the first edition. The textual history of this masterpiece of war fiction is complete in this volume.

\section{JOURNAL OF GLASS STUDIES}

(Corning Museum of Glass)

Volume XIV. 1972. \$15.00 Volume XV. 1973. \$15.00

The articles in these publications range among all the historical periods in which glass has been made, from the fifteenth century B.C. to the present. The editorial board and contributors, all internationally known scholars, present the most thorough research on the art and history of glassmaking available. Highly readable and lavishly illustrated, the Journal is indispensable to the specialist, collector, and to the general reader who wishes to know more about glass.

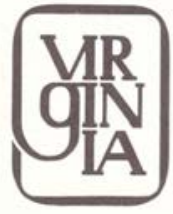

\author{
University Press of Virginia \\ Box 3608 University Station \\ Charlottesville, Virginia 22903
}




\section{NEW from Faxon The Fifth Supplement to the Index To Handicrafts}

The INDEX TO HANDICRAFTS series covers miscellaneous and previously uncollected material on handicrafts and amateur workshop projects. The original Index and four successive supplements cover from roughly 1900 to 1967. The new Fifth Supplement, by Pearl Turner, covers 1968-1973 and includes not only American, but also British titles commonly found in public libraries. Over 1,000 book titles and 15 periodicals not indexed by the Reader's Guide to Periodical Literature are included, as well as a separate bibliography listing all books now still-in-print from the titles indexed in the previous Index and Supplement. For a complete description of the Handicrafts series, request a copy of Faxon's Publications Catalog. All previous volumes are available at $\$ 14.00$ each. Order the entire series now and receive a special pre-publication discount of $10 \%$.

ISBN 0-87305-102-5, 629 pp., Cloth, \$18.00.

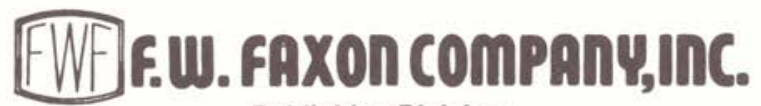

Publishing Division

15 Southwest Park, Westwood, Mass. 02090

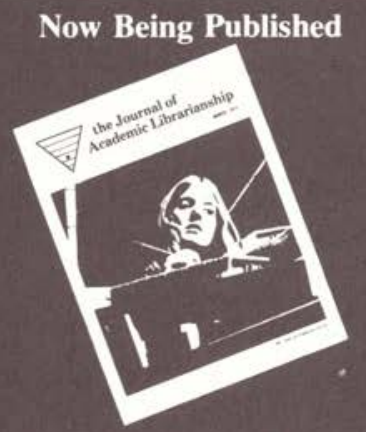

The Journal

of Academic Librarianship

A bimonthly journal for the professional librarian
An independent voice providing:

- statements on the current and difficult issues facing academic librarians and the results of significant research

- the JAL Guide - key to the literature of librarianship

- articles by academic librarians on specialized topics

- pictorial features on innovative services offered by academic libraries

- In coming issues: Ralph E. Ellsworth, Fred Heinritz, John Rather, Martha Boaz, Duane Webster, Paul Dunkin, Maryan Reynolds

- Writing on: subjects which include change in academic libraries, collective bargaining, faculty status, cataloging, buildings, and networks of the future

Edited by: Richard M. Dougherty and William H. Webb

The Journal of
$\begin{aligned} & \text { Academic Librarianship } \\ & \text { Subscription Dept. } \\ & \text { P.O. Box } 3496\end{aligned}$
Boulder, Colo. 80303




\section{YES,}

\section{We Make}

Mistakes!

Even though they are rare, we are human at the Book House and we make mistakes on occasion!

Does it surprise you that we admit to being human? We are human and we treat you like you are human - as friendly, cooperative counsellors and advisors who are prepared to serve you as efficiently and quickly as possible.

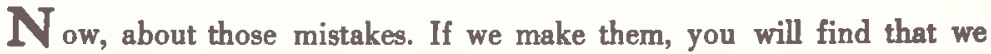
will correct them with a minimum of problems for you. No computer will keep repeating the same error of title, edition, price or credit for return.

$T$ he human side of this business is what we enjoy - our contacts with you - our efforts to please you are the real joys of this business for everyone of the Book House professionals.

B ook House will deliver any book in print including all university presses, professional and non-profit associations, Government publications, Canadian titles and ALL paperbacks. Why not give Book House a trial order and find out what human, Concerned Service can do for you! Just let us know if you want to receive our occasional newsletter.

\section{ANY QUESTIONS? CALL 517-849-9361 COLLECT!}

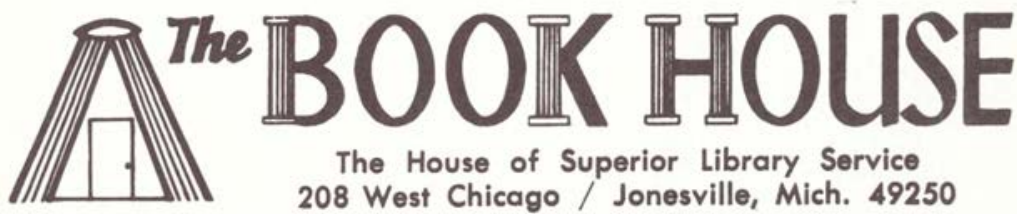




\section{Abstracts of the best articles from the last 20 years.}

(ISBN 0-87436-178-8)

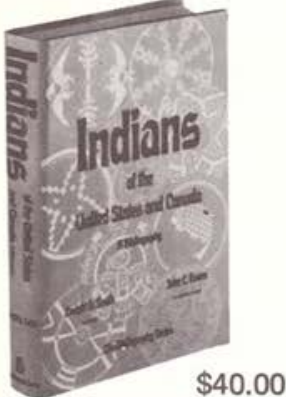

(ISBN 0-87436-124-9)

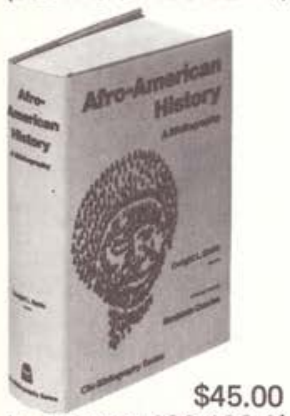

(ISBN 0-87436-123-0)

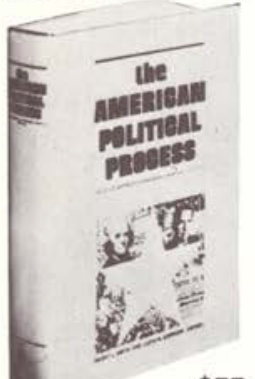

$\$ 55.00$

(ISBN 0-87436-090-0)
Each Clio Bibliography is a compilation of abstracts of scholarly articles in special subject areas. The coverage is from 1954 to the present, and encompasses over 2,000 journals in history and the related humanities. Each Clio Bibliography contains a subject-author-biographic-geographic index.

New: Era of the American Revolution: A Bicentennial Bibliography, edited by Dwight L. Smith, with an introduction by Richard B. Morris, President of the American Historical Association. Contains 1,401 abstracts of articles published between 1954 and 1974. Includes author-subjectbiographic-geographic index.

The Clio Bibliographies offer the surest and fastest access to the periodical literature in subjects of current interest to scholars and students. (And abstracts tell you so much more.)

Upcoming titles include: The Role of Women in American History; American Urban History \& Life.

Eric H. Boehm, Editor

Standing order receives $10 \%$ discount on all titles. Orders from individuals must be prepaid.

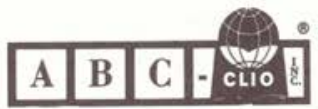




\section{Three timely reports on library susiems from"the authority"}

Automated Circulation Control Systems: An Overview of Commercially Vended Systems

An extensive discussion by Barbara Evans Markuson of the characteristics of five circulation control systems, including CLSI, Checkpoint/Plessey, and Check-A-Book. In the July \& September 1975 issues of LTR. $\$ 35$.

\section{Microform Catalog Data Retrieval Systems}

A comparison of Information Design. Information Dynamics, and Library Processing Systems. In the May 1975 issue of LTR. $\mathbf{\$ 2 0}$.

\section{Theft Detection Systems for Libraries}

A revealing and valuable 98 -page survey of manufacturers and users. In the May 1974 issue of LTR. $\mathbf{\$ 2 0}$.

\section{Library Technology Reports (LTR)} is a unique bimonthly publication of the American Library Association that provides critical evaluations of products used in libraries, media centers, schools, and other educational institutions. Its purpose is twofold: to enable librarians and educators to make economical purchase decisions and to alert manufacturers of library needs and standards of performance expected.

To order any of the above individual issues or for additional iniormation on the complete subscription service, write to:

\section{LIBRARY TECHNOLOGY REPORTS} American Library Association 50 East Huron Street Chicago, Illinois 60611

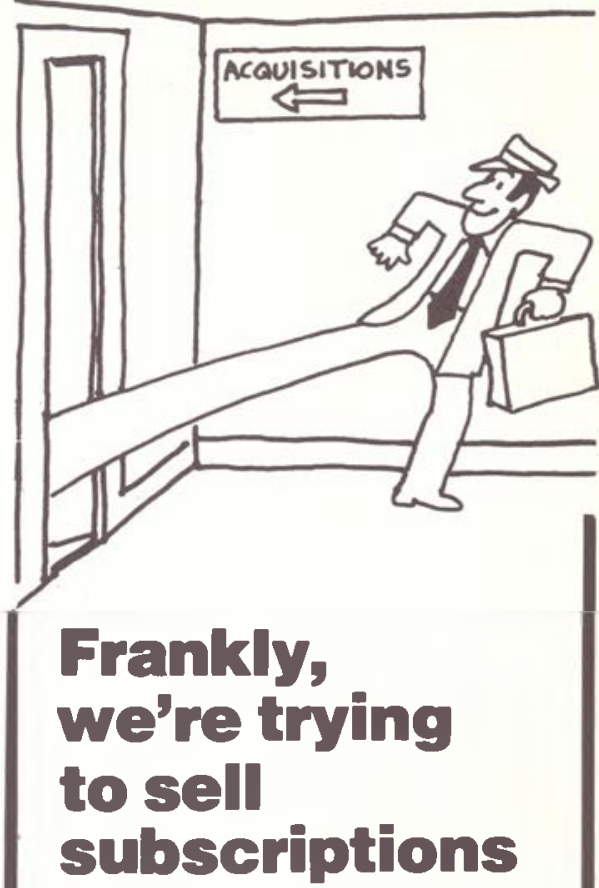

Have you heard?

For the first time, american libraries is now available on subscription to any library, whether or not it's a member of ALA. And any member library that already gets one copy of $A L$ can now get more than one. So no member of the staff has to wait while one copy slowly circulates and our hot news grows tepid. Your patrons might enjoy it, too. After all, they like libraries, don't they?

\section{$\$ 20.00$ for eleven issues per year. \\ That's our price.}

\section{american libraries}

50 East Huron Street, Chicago 60611 


\section{We don't promise to be all things to all libraries.}

\section{But these things we do promise.}

\section{Prompt and Accurate Order Fultillment}

Bro-Dart knows the importance of fast order fulfillment. That's why we get you the books you want when you want them. We'll fill your orders immediately from one of North America's largest book inventories, and for those titles not in stock, our qutomated back-order system (considered the most efficient in operation) will rapidly provide your titles.

\section{Vigilant Reporting and Executive Customer Service}

In performing the jobber function of keeping libraries sup plied with the latest published materials, Bro-Dart employs the most modern technology in the industry. A monthly notice tells you of all cancellations and their reasons. Our final cancellation notice lists all unavailable titles for the period. At the end of any given order period, this complete reporting service lets you clear your files so you are always up-to- date. And with all this technical accuracy and efficiency there is an account executive assigned to your library to satisfy your every need.

\section{Trouble-Free}

\section{Continuations Service}

This open-ended program covers English language monographic series, sets in progress and non-subscription serials published or distributed in North America. Here, too, the combina tion of advanced technology and a highly-trained and experienced staff provides fast shipment and thoroughly up-to-date information on all titles. You always know what's been published (or delayed) through your monthly status report.

\section{Technical Services}

In addition to efficient book supply services, Bro-Dart has the most accurate and comprehensive cataloging and processing commercially available. This service, TECH-SERV ${ }^{\ominus}$, can provide complete book processing kits with or without protective covers with either Library of Congress or Unabridged Dewey Classification matched with every book delivered, if desired!

While we don't promise to be all things to all libraries, we intend to come real close.... Send us your orders.

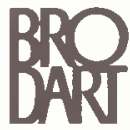

1609 Memorial Avenue Williamsport, PA 17701 


\section{Buying full-text copies of journal articles as few as 5 at a time?}

Then you'll probably find our Original Article Tear Sheet (OATS $\left.{ }^{\otimes}\right)$ service is faster, better and less expensive than any other source of full-text copies.

Certainly you've at least heard about OATS. The service that usually provides actual tear sheets of articles, not just photocopies. The multidisciplinary service you can count on for all-but-instant response to just about any request.

Yet perhaps you still hesitate to use OATS because you feel any service that good must be expensive. If so, you've just caught up with another "must be" that isn't. Here's what OATS really costs any time you can order as few as 5 journal articles at once:

\begin{tabular}{|cc|}
\hline $\begin{array}{c}\text { No. of Items } \\
\text { Ordered } \\
\text { at One Time }\end{array}$ & $\begin{array}{c}\text { Cost per } \\
\text { 10-Page } \\
\text { Item }\end{array}$ \\
\hline $5-10$ & $\$ 3.40$ \\
\hline $11-20$ & 3.35 \\
\hline $21-30$ & 3.30 \\
\hline $31-50$ & 3.25 \\
\hline $51-100$ & 3.20 \\
\hline Over 100 & 3.15 \\
\hline
\end{tabular}

Compare our prices to those charged by other full-text sources. You'll find we're more than competitive. Place an order, and you'll find our service is, too. Or, for more information before you order, mail the coupon to OATS specialist Alan Clarke. You'll hear from him.

\section{Yes, Alan Clarke, I like those OATS prices and the idea of one-stop}

shopping for journal items. So...

Mail me more information.

Phone me.

Have an ISI field rep contact me.

Name Phone No.

Organization

Address

City

State

Province

Zip 